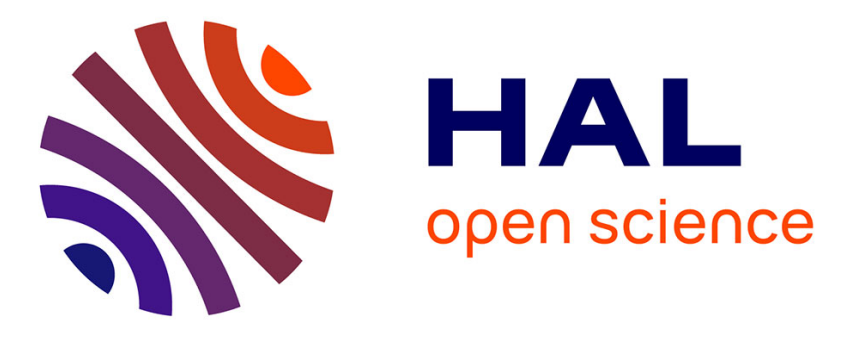

\title{
Patterns of silver eel (Anguilla anguilla L.) sex ratio in a catchment
}

Pascal Laffaille, Anthony Acou, Jérôme Guillouët, Béatrice Mounaix, Antoine Legault

\section{- To cite this version:}

Pascal Laffaille, Anthony Acou, Jérôme Guillouët, Béatrice Mounaix, Antoine Legault. Patterns of silver eel (Anguilla anguilla L.) sex ratio in a catchment. Ecology of Freshwater, 2006, 15, pp. 583-588. 10.1111/j.1600-0633.2006.00195.x . hal-00793405

\section{HAL Id: hal-00793405 https://hal.science/hal-00793405}

Submitted on 22 Feb 2013

HAL is a multi-disciplinary open access archive for the deposit and dissemination of scientific research documents, whether they are published or not. The documents may come from teaching and research institutions in France or abroad, or from public or private research centers.
L'archive ouverte pluridisciplinaire HAL, est destinée au dépôt et à la diffusion de documents scientifiques de niveau recherche, publiés ou non, émanant des établissements d'enseignement et de recherche français ou étrangers, des laboratoires publics ou privés. 


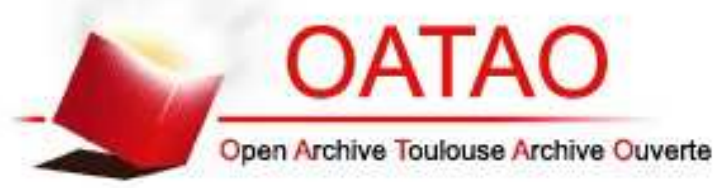

\section{Open Archive Toulouse Archive Ouverte (OATAO)}

OATAO is an open access repository that collects the work of Toulouse researchers and makes it freely available over the web where possible.

This is an author-deposited version published in: http://oatao.univ-toulouse.fr/ Eprints ID: 6199

To link to this article: DOI:10.1111/j.1600-0633.2006.00195.x URL: http://dx.doi.org/10.1111/j.1600-0633.2006.00195.x

To cite this version: Laffaille, Pascal and Acou, Anthony and Guillouët, Jérôme and Mounaix, Béatrice and Legault, Antoine Patterns of silver eel (Anguilla anguilla L.) sex ratio in a catchment. (2006) Ecology of Freshwater, Vol. 15 ( $\left.{ }^{\circ} 4\right)$. pp. 583-588. ISSN 0906-6691

Any correspondence concerning this service should be sent to the repository administrator: staff-oatao@listes-diff.inp-toulouse.fr 


\section{Patterns of silver eel (Anguilla anguilla L.) sex ratio in a catchment}

Laffaille P, Acou A, Guillouët J, Mounaix B, Legault A. Patterns of silver eel (Anguilla anguilla L.) sex ratio in a catchment.

Abstract - Changes in the numbers and size-class structure of European silver eels, Anguilla anguilla, in the River Frémur (France) were examined over a 9-year period after installation of downstream eel passes. The number of silver eels migrating downstream peaked in 1999, then decreased strongly and steadily after 2000, reaching relatively low levels. At the same time, a gradual shift in the silver eel sex ratio from a dominance of males (size from 270 to $442 \mathrm{~mm}$, age from 3 to 6 years) to females (size from 366 to $1112 \mathrm{~mm}$, age from 4 to 9 years) was recorded. Possible explanations for the escapement patterns observed are environmental sex determination and the installation of eel passes on the main hydraulic engineering structures in 1992 and 1996.

\author{
P. Laffaille ${ }^{1}$, A. Acou' ${ }^{1}$, J. Guillouët ${ }^{2}$, \\ B. Mounaix ${ }^{2}$, A. Legault ${ }^{2}$ \\ ${ }^{1}$ Equipe de Recherche Technologique 52 \\ 'Biodiversité Fonctionnelle et Gestion des \\ Territoires', Université de Rennes 1, Rennes, \\ France, ${ }^{2}$ Fish Pass, 8 allée de Guerlédan, ZA Parc \\ Rocade Sud, Chantepie, France
}

Key words European eel; downstream migration; sex ratio; eel passes; environmental sex determination

P. Laffaille, Université de Rennes 1, Equipe de Recherche Technologique 52 'Biodiversité Fonctionnelle et Gestion des Territoires', Bâtiment 25 Campus de Beaulieu, 35042 Rennes, France; e-mail: plaffaille@hotmail.com or pascal.laffaille@univ-rennes1.fr

\section{Introduction}

The European eel Anguilla anguilla (L.) has steadily declined throughout its distribution range since 1980 (Dekker 2003). Consequently, the current effective population size is low and the population has undergone severe regression (Wirth \& Bernatchez 2003). Because of the recent scarcity of this species, ICES recently recommended that all means should be used to restore the depleted stocks, at all biological stages. A stock recovery plan is urgently needed, especially for silver eels (Feunteun 2002), but monitoring methods needed to be established (Baisez \& Laffaille 2005). Monitoring methods now exist and have been used for glass eels and yellow eels in a range of systems throughout Europe (for example in the French river Frémur, Legault et al. 2004; Laffaille et al. 2005), but little work has been conducted on silver eels (for example Holmgren et al. 1997; Feunteun et al. 2000; Rosell et al. 2005).

Whatever the reasons for the decline (overexploitation, changes in oceanographic conditions, pollution, parasitism, degradation of freshwater habitats, reductions in accessible freshwater habitat, see for example: Moriarty \& Dekker 1997; Feunteun 2002), Russell \& Potter (2003) suggested that the principles of the precautionary approach are directly relevant to the management of European eel stock. The application of this approach should relate to fisheries and nonfisheries factors such as the management of freshwater, estuarine and coastal habitats. Dam construction has been identified as a major factor responsible for the severe reduction of freshwater eel stocks. Consequently, a number of attempts could be conducted to manage freshwater habitat availability and connectivity, such as elimination of physical obstructions to migration in particular by installing eel passes (Knights \& White 1998; Legault et al. 2004).

The Frémur is a small French river in northern Brittany. This river appears to be representative of many small coastal catchments of the Atlantic coast. The natural connectivity has been disturbed by several hydraulic barriers, especially by three high dams, which inhibit eel migration and reduce recruitment by elvers and yellow eels. One of the dams was totally impassable (Bois Joli) because it is a $14 \mathrm{~m}$ high totally vertical dam and the dam wall was completely dry during the upstream migration season. In 1992, the Bois Joli Dam was equipped with an eel lift to permit elvers to migrate upstream. Two downstream dams (Pont Avet, $6 \mathrm{~m}$ high and Pont es Omnès, $4 \mathrm{~m}$ high) were partially impassable until they were equipped 
with eel passes in 1996. An important question arose from this situation: what are the effects of specific equipment such as eel passes on the annual changes in downstream eel migration? The aim of this study was to analyse the temporal changes in European silver eels, using a 9-year monitoring programme in the Frémur River after the passes were installed.

\section{Material and methods}

The Frémur flows into the Channel next to Saint-Malo (Brittany). Its catchment covers about $60 \mathrm{~km}^{2}$ and the overall length of the river and its tributaries is $45 \mathrm{~km}$, comprising $17 \mathrm{~km}$ for the main stream. The slope varies between $0.1 \%$ and $2 \%$ with an average of $0.6 \%$. Despite its small size, the Frémur contains a wide range of habitats from high-velocity streams typical of the trout zone to lentic waters of the bream zone in downstream areas, man-made ponds and reservoirs, wetlands, etc. Fishing pressure is quite low on this river with no commercial eel fisheries and anglers mainly focussing on cyprinids, perch, zander and pike in ponds and reservoirs.

Upstream migration was monitored daily using an eel trap (see Feunteun et al. 2000) from 1996 to 2004. Yearly trends in silver eel abundance were analysed using a Pearson correlation. The proportions of eels $>450 \mathrm{~mm}$ were compared using a chi-square test and the Simultaneous Test Procedure according to Sokal \& Rohlf (1981). We collected a subsample of 114 eels (individual size ranged from 311 to $794 \mathrm{~mm}$ ) in the trap between 2001 and 2003 to estimate ages and sex ratio of eels migrating upstream. We removed and embedded one sagittal otolith per fish in methacrylate resin. This was ground at the sagittal plane and polished until the nucleus was exposed. Then we etched the sagittal surface with 5\% EDTA (Mounaix 1993). We interpreted otoliths and defined the age of each eel using scanning electron microscopy (SEM,
JSM-6301F, JEOL, Tokyo, Japan). The gonads of this subsample were examined macroscopically to determine the sex ratio of eels migrating upstream using the method of Colombo et al. (1984).

\section{Results}

A total of 6650 silver eels were caught in the downstream migration trap. The mean length $( \pm \mathrm{SD})$ of descending eels was $441 \pm 115 \mathrm{~mm}$ (min: $270 \mathrm{~mm}$ and max: $1112 \mathrm{~mm}$ ) (Fig. 1). Each year, the size structure of silver eel appeared to be bimodal: $<450$ and $>450 \mathrm{~mm}$. The examination of gonads confirmed that the first group represents mainly males (during our study only $10 \%$ of eels $<450 \mathrm{~mm}$ were female) and the second exclusively females (Fig. 2). The overlap between the male and female size distributions is common in some catchments (Haraldstad et al. 1985; Vollestad \& Jonsson 1988; Rosell et al. 2005) and eel farms (Holmgren 1996). Ten per cent of eels caught in the downstream trap were sexually undifferentiated. Gonad differentiation of eels usually begins at 150 $250 \mathrm{~mm}$ body length, but some individuals as long as $350 \mathrm{~mm}$ can still be sexually undifferentiated (Bienarz et al. 1981). Males were 3-6 years old (mean \pm SD: $4.3 \pm 0.9$ years; but $74 \%$ were $4-5$ years old) and measured $270-442 \mathrm{~mm} \quad(372 \pm 25 \mathrm{~mm})$. Females were $4-9$ years old $(5.5 \pm 1.1$ years; but $83 \%$ were 4-6 years old) and measured $366-1112 \mathrm{~mm}$ $(590 \pm 97 \mathrm{~mm})$.

The total number of descending eels (Fig. 3) was relatively stable from 1996 to 1998 (annual mean 811 eels, range 729-885 silver eels). A peak appeared in 1999 (1362 silver eels). Between 2001 and 2004, the total number declined 2.5-fold (annual mean 461, range 314-585 silver eels). The decrease from 1999 to 2004 was significant both in males (Pearson's $r=-0.88 ; \quad P=0.02$ ) and females (Pearson's $r=-0.87 ; P=0.03$ ). But, the number of males

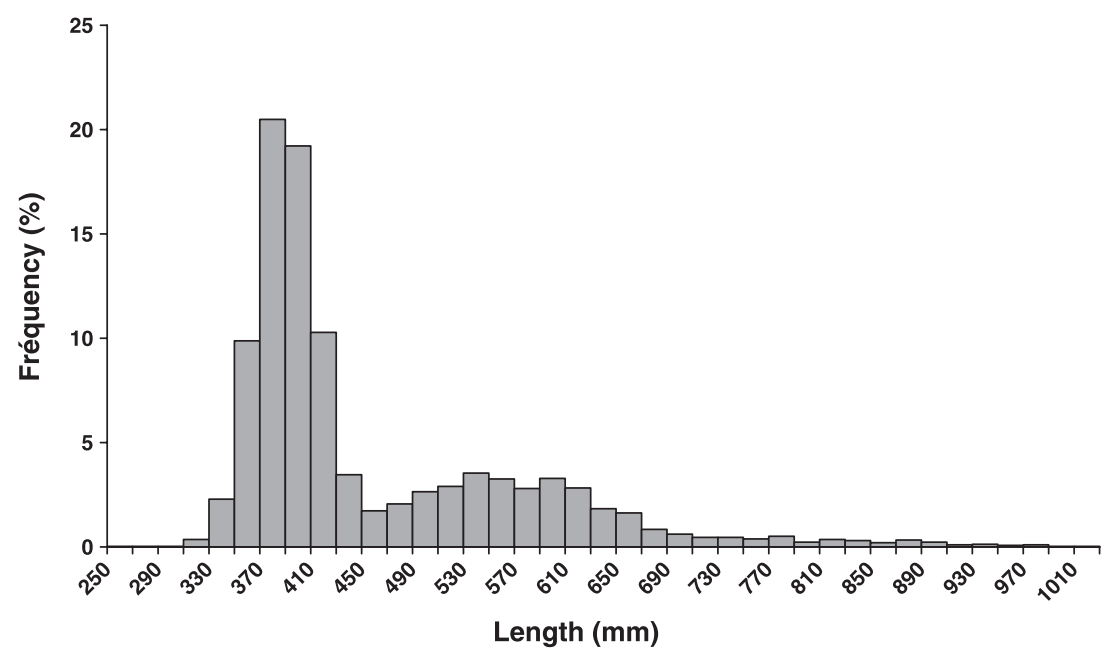

Fig. 1. Population structure of silver eels caught in a downstream trap in the French river Frémur (Brittany) during a 9-year study (1999-2004). $N=6650$. 
Fig. 2. Sex ratio of the silver eel population caught in the downstream trap in relation to size classes.
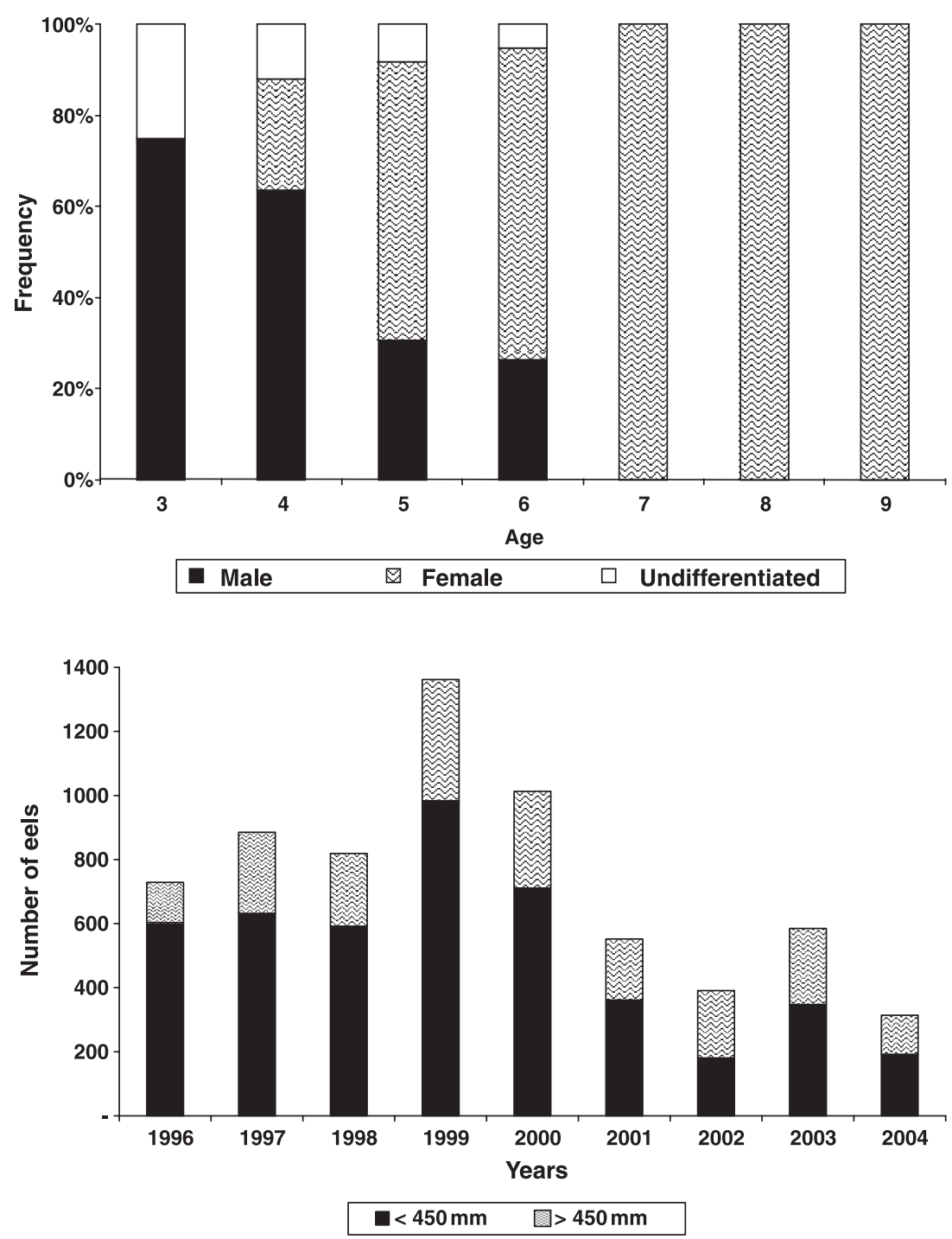

Fig. 3. Number of silver eels caught in the downstream trap during the 9-year study in relation to the length structure. recruitment and catchment characteristics. Generally, male silver eels are more abundant at high densities, whereas females predominate at low densities in natural (Parsons et al. 1977; Vollestad \& Jonsson 1988; Acou et al. in press) and farming conditions (Egusa 1979; Holmgren 1996). The Frémur is a small river with high yellow eel densities (mean density 50 eels per $100 \mathrm{~m}^{2}$ ) in the whole river system (Laffaille et al. 2005). Consequently, males predominated (on average $69 \%$ of catches) in the downstream trap of the Frémur during the whole study period. The estimated silver eel density was 4.5-fold higher in the Frémur than in the Oir River (Normandy, France), a similar small neighbouring catchment (Acou et al. in press). Silver eels were dominated by females in the Oir (79\%), where mean density of eel was 16-fold lower (mean density 3 eels per $100 \mathrm{~m}^{2}$ ). The Frémur eel densities are very high compared to other French catchments (Conseil Supérieur de la Pêche, personal communication) and west European catchments

European eel sex determination has been related to the environment and especially to population density, 
(Moriarty \& Dekker 1997). For example, Carss et al. (1999) reported that $71 \%$ of density estimates at 1462 sites in English rivers and streams were $<5$ eels per $100 \mathrm{~m}^{2}$. Consequently and according to the sex ratioeel density relationships, female silver eels are certainly dominant in some European catchments.

We found a relative stability in the number of silver eels migrating downstream from 1996 to 1998 and a peak in 1999 and 2000 in the Frémur catchment. One possible explanation for this observed escapement pattern is the provision of the eel-lift on the Bois Joli Reservoir Dam in 1992 and then passes on the Pont Avet and Pont es Omnes reservoir dams further downstream in 1996. These would have allowed eels that had accumulated below the dams to pass upriver, leading to a rapid but short-lived increase in fluvial recruitment and consequently in densities upstream (Feunteun et al. 1998). High densities would favour the production of males and the silver males accounted for $83-70 \%$ of catches in the downstream trap during this period. This recruitment-sex ratio relationships is supported by some results and especially because changes in recruitment have been implicated indirectly in sex ratios bias in some experimental lakes, which were stocked with cultured eels (Parsons et al. 1977; Wickström et al. 1996; Holmgren et al. 1997) and in natural system (Rossi et al. 1988; Poole et al. 1990). In the Frémur, the turnover was rapid especially for males. Males stayed in the catchment area for 45 years and females for 4-6 years. If the majority of silver males migrate when 4-5 years old, then high silver eel trap catches would be expected 4-5 years after the installation of fish passes (in 1996), with peaks in 1999 and 2000 as observed. These duration and results were similar to Holmgren et al. (1997).

During the period 1999-2004, the number of silver eels decreased with the males threefold more rapidly than females. Consequently, the proportion of male silver eels has rapidly decreased to $65-46 \%$ and inversely females accounted for $42 \%$ of total silver eels. One possible explanation is still due to the decline in recruitment observed in the Frémur (Legault et al. 2004). But, there is some evidence suggesting that habitat characteristics may have an indirect role on sex ratio within a catchment. Accordingly, eels may choose a habitat that best fits their life history strategy (Helfman et al. 1987). Environmental sex determination would require that the characteristics of the environment where a young eel ends up determine its final size and consequently its sex. Indeed, some studies have suggested size-habitat relationships in eels Generally, large eels (the future females) are absent or rare in shallow habitats, tending to be found rather in deep waters either in streams (Laffaille et al. 2003) or in marsh systems (Laffaille et al. 2004). Moreover, the proportion of lacustrine habitat in a catchment apparently influences the sex distribution and plays a role in sex determination (Bergersen \& Klemetsen 1988; Oliveira et al. 2001). The total water area in the Frémur system is approximately 75 ha of which 5 ha is running waters and 70 ha still waters (ponds and reservoirs). The size frequency distribution showed that female yellow eels dominate in still waters and male yellow eels dominate in streams (Feunteun et al. 1998). The standing waters of the Frémur are certainly the principal reservoir for potential females and running waters for potential males. The numbers of female silver eels emigrating may have remained relatively more stable than males in the Frémur. This may be because the 5 ha of river habitats are saturated at carrying capacity (Laffaille et al. 2005), forcing relatively more eels to use the 70 ha of reservoirs (especially Bois Joli) that produce large eels (i.e., the future females).

Another possible explanation for the declines in trap catches is the variation in rainfall and river flow. Feunteun et al. (2000) found that few eels were caught unless the Bois Joli Reservoir was full and they were able to pass in the flow over the dam, whereas mortality occurred amongst eels passing through the compensation flow discharge pipe (Legault et al. 2003). However, rainfall and river flow do not explain the shift in the sex ratio. Other factors such as trophic status of the aquatic ecosystem may also influence sex determination. Observations on European eels suggest a causal relationship between feeding conditions and/ or temperature and sex differentiation (Lammens \& Visser 1990; Holmgren 1996; Beullens et al. 1997). In the Frémur, there has been an increase in the size of silver eels and change in the sex ratio, possibly related to growth conditions resulting from an increase in the trophic status and water temperature. Another possible factor in the shift of the sex ratio is the potential feminisation resulting from pollution by oestrogen-like substances that has been reported in freshwater fish in some European rivers (see for example Jobling et al. 1998). However, the trophic and the chemical water quality has not changed in the Frémur (Guillouët et al. 2004).

Given the life cycle and relative longevity of the eel, declining recruitment will have a delayed effect on eel densities in freshwater systems and the resulting spawning escapement (Dekker 2003). Thus, recent declines in recruitment could lead to a continuing reduction in the number of potential spawners such as in the Frémur River. The problem is the depensatory processes that operate at low stock levels (Liermann \& Hilborn 1997), if for example silver eels find it difficult to find mates at low spawner densities in the Sargasso Sea. Dekker (2003) suggested that both freshwater and spawning stocks must have declined in parallel, and insufficient spawning stock biomass 
might have caused the recruitment collapse currently observed. Consequently, the observed decrease of the silver eel stocks and gradual shift of silver eel sex ratio from male to female could continue in the forthcoming years. This trend is certainly general throughout the European eel distribution range. These consequences should be taken into account in the global and local management plan. This species is outside safe biological limits, and therefore, application of the precautionary principle approach for the management of the European eel is necessary (Russell \& Potter 2003). This study has established the importance of the silver eel sex ratio monitoring that can now be used in the eel reporting card systems in use at the catchment scale (Baisez \& Laffaille 2005).

\section{Acknowledgements}

This study was funded by the 'Fédération de Pêche et de Protection des Milieux Aquatiques d'Ille et Vilaine', the 'Contrat de Plan Poissons Migrateurs' and various regional and local councils. We thank the anonymous referees for many helpful suggestions.

\section{References}

Acou, A., Gabriel, G., Laffaille, P. \& Feunteun, E. in press. Differential production and condition indices of premigrant eels (Anguilla anguilla) in two Atlantic coastal catchments of France. American Fisheries Society Symposium ??: ???

Baisez, A. \& Laffaille, P. 2005. Un outil d'aide à la gestion de l'anguille: le tableau de bord anguille du bassin Loire. Bulletin Français de la Pêche et de la Pisciculture 378-379: 115-130.

Bergersen, R. \& Klemetsen, A. 1988. Freshwater eel Anguilla anguilla (L.) from north Norway with emphasis on occurrence, food, age and downstream migration. Nordic Journal of Freshwater Research 64: 54-66.

Beullens, K., Eding, E.H., Gilson, P., Ollevier, F., Komen, J. \& Richter, C.J.J. 1997. Gonadal differentiation, intersexuality and sex ratios of European eel (Anguilla anguilla L.) maintained in captivity. Aquaculture 153: 135-150.

Bienarz, K., Epler, P., Malczewski, B. \& Passakas, T. 1981. Development of European eel (Anguilla anguilla L.) gonads in artificial conditions. Aquaculture 22: 53-66.

Carss, D.N., Elston, D.A., Nelson, K.C. \& Kruuk, H. 1999. Spatial and temporal trends in unexploited yellow eel stocks in two shallow lakes and associated streams. Journal of Fish Biology 55: 636-654.

Colombo, G., Grandi, G. \& Rossi, R. 1984. Gonad differentiation and body growth in Anguilla anguilla, L. Journal of Fish Biology 24: 215-228.

Dekker, W. 2003. Did lack of spawners cause the collapse of the European eel, Anguilla anguilla? Fisheries Management and Ecology 10: 365-376.

Egusa, S. 1979. Notes on the culture of the European eel (Anguilla anguilla L.) in Japanese eel-farming ponds. Rapports et P.V. des Réunions du Conseil International de l'Exploration de la Mer 174: 51-58.
Feunteun, E. 2002. Management and restoration of European eel population (Anguilla anguilla): an impossible bargain. Ecological Engineering 18: 575-591.

Feunteun, E., Acou, A., Guillouët, J., Laffaille, P. \& Legault, A. 1998. Spatial distribution of an eel population (Anguilla anguilla L.) in a small coastal catchment of Northern Brittany (France). Consequences of hydraulic works. Bulletin Français de la Pêche et de la Pisciculture 349: 129-139.

Feunteun, E., Acou, A., Laffaille, P. \& Legault, A. 2000. European eel (Anguilla anguilla): prediction of spawner escapement from continental population parameters. Canadian Journal of Fisheries and Aquatic Sciences 57: $1627-1635$.

Guillouët, J., Acou, A., Laffaille, P., Mounaix, B., Legault, A. \& Feunteun, E. 2004. Etude de la restauration de la population d'anguille sur le Frémur: suivi post-aménagement, année 2004. Rennes: Report Fish-Pass, University of Rennes 1, Fédération de Pêche et de Protection des Milieux Aquatiques d'Ille et Vilaine, $83 \mathrm{pp}$.

Haraldstad, O., Vollestad, L.A. \& Jonsson, B. 1985. Descent of European silver eels, Anguilla anguilla L., in a Norwegian watercourse. Journal of Fish Biology 26: 37-41.

Helfman, G.S., Facey, D.E., Hales, L.S. Jr \& Bozeman, E.L. Jr 1987. Reproductive ecology of the American eel. American Fisheries Society Symposium 1: 42-56.

Holmgren, K. 1996. Effect of water temperature and growth variation on the sex ratio of experimentally reared eels. Ecology of Freshwater Fish 5: 203-212.

Holmgren, K., Wickström, H. \& Clevestam, P. 1997. Sexrelated growth of European eel, Anguilla anguilla, with focus on median silver eel age. Canadian Journal of Fisheries and Aquatic Sciences 54: 2775-2781.

Jobling, S., Nolan, M., Tyler, C.R. \& Sumpter, J.P. 1998. Widespread sexual disruption in wild fish. Environmental Science and Technology 32: 2498-2506.

Knights, B. \& White, E. 1998. Enhancing immigration and recruitment of eels: the use of passes and associated trapping system. Fisheries Management and Ecology 5: 459-471.

Laffaille, P., Feunteun, E., Baisez, A., Robinet, T., Acou, T., Legault, A. \& Lek, S. 2003. Spatial organisation of European eel (Anguilla anguilla L.) in a small catchment. Ecology of Freshwater Fish 12: 254-264.

Laffaille, P., Baisez, A., Rigaud, C. \& Feunteun, E. 2004. Habitat preferences of different European eel size classes in a reclaimed marsh: a contribution to species and ecosystem conservation. Wetlands 24: 642-651.

Laffaille, P., Acou, G., Guillouët, J. \& Legault, A. 2005. Temporal changes in European eel, Anguilla anguilla, stocks in a small catchment after installation of fish passes. Fisheries Management and Ecology 12: 123-129.

Lammens, E.H.R.R. \& Visser, J.T. 1990. Variability in mouth width in European eel, Anguilla anguilla, in relation to varying feeding conditions in three Dutch lakes. Environmental Biology of Fishes 6: 63-75.

Legault, A., Acou, A., Guillouët, G. \& Feunteun, E. 2003. Survey of downstream migration of silver eels through discharge pipe on a reservoir dam. Bulletin Français de la Pêche et de la Pisciculture 368: 43-54.

Legault, A., Laffaille, P., Guillouët, J. \& Acou, A. 2004. Importance of specific fish passes for European eel (Anguilla anguilla L.) recruitment. In: De Jalon Lastra, D.G. \& 
Martinez, P.V., eds. Proceedings of the fifth international symposium on ecohydraulics. Aquatic habitat: analysis \& restoration. Madrid: IAHR, pp. 937-941.

Liermann, M. \& Hilborn, R. 1997. Depensation in fish stocks: a hierarchic Bayesian meta-analysis. Canadian Journal of Fish and Aquatic Sciences 54: 1976-1984.

Moriarty, C. \& Dekker, W. (eds) 1997. Management of European eel fisheries. Fishery Bulletin 15: 1-110.

Mounaix, B. 1993. Intercalibration and validation of methods to estimate age of the European eel (Anguilla anguilla L.). Application in the catchment area of the river Vilaine, Brittany. Cybium 17: 259-260.

Oliveira, K., McCleave, J.D. \& Wippelhauser, G.S. 2001. Regional variation and the effect of lake: river area on sex distribution of American eels. Journal of Fish Biology 58: 943-952.

Parsons, J., Vickers, K. \& Warden, Y. 1977. Relationship between elver recruitment and changes in the sex ratio of silver eels Anguilla anguilla L. migrating from Lough Neagh, Northern Ireland. Journal of Fish Biology 10: 211229.

Poole, W.R., Reynolds, J.D. \& Moriarty, C. 1990. Observations on the silver eel migrations of the Burrishoole River system, Ireland, 1959 to 1988. International Revue des Gesamten Hydrobiologie 75: 807-815.
Rosell, R., Evans, D. \& Allen, M. 2005. The eel fishery in Lough Neagh, Northern Ireland - an example of sustainable management? Fisheries Management and Ecology 12: 377-385.

Rossi, R., Carrieri, A., Franzoi, P., Cavallini, G. \& Gnes, A. 1988. A study of eel (Anguilla anguilla L.) population dynamics in the Comacchio lagoons (Italy) by markrecapture method. Oebalia 14: 87-106.

Russell, I.C. \& Potter, E.C.E. 2003. Implications of the precautionary approach for the management of the European eel, Anguilla anguilla. Fisheries Management and Ecology 10: 395-401.

Sokal, R.R. \& Rohlf, F.J. 1981. Biometry. The principles and practice of statistics in biological research, 2nd Edition. New York: W.H. Freeman and Company.

Vollestad, L.A. \& Jonsson, B. 1988. A 13-year study of the population dynamics and growth of the European eel Anguilla anguilla in a Norwegian river: evidence for density-dependent mortality, and development of a model for predicting yield. Journal of Animal Ecology 57: 983-997.

Wickström, H., Westin, L. \& Clevestam, P. 1996. The biological and economical yield from a long-term stocking experiment. Ecology of Freshwater Fish 5: 140-147.

Wirth, T. \& Bernatchez, L. 2003. Decline of North Atlantic eels: a fatal synergy? Proceedings of the Royal Society of London B, Biological Sciences 270: 681-688. 